I. Mironova

\section{THE PRACTICE OF COMBATING ALCOHOL ABUSE IN THE RURAL POPULATION OF SOUTHERN UKRAINE (SECOND HALF OF XIX - EARLY XX CENTURIES)}

Introduction. Alcoholism is a large-scale social problem that disrupts the socio-economic life of society. The rise of alcohol abuse is observed in rural areas and primary caused by unemployment and limited cultural leisure opportunities. It is significant to consider the experience gained in combating this phenomenon in the second half of the XIX - the beginning of the $X X$ centuries for developing the concept of overcoming alcoholism.

Purpose. The aim of the article is to analyze the activities of the state government, the public, the clergy and the Guardianships of Public Sobriety in the field of combating alcoholism among the rural population of Southern Ukraine for a certain period.

Methods. The interdisciplinary nature of the study led to the application of a modernization approach, which considered the anti-alcohol issue in Ukrainian society.

Results. The abolition of serfdom caused a sharp surge in rural drunkenness. In the South of Ukraine, the wine industry was developed and operated under the conditions of the redemption system. That system brought great profit to the state and a narrow group of redemption merchants. When the excise system was introduced in 1863, a tax was levied on every sold bucket of vodka; spirits were produced in private factories, vodka was sold in pubs. Improvements in bread sales in other governorates (i.e. provinces) and abroad due to the development of communication routes have become the core causes of the regional wine industry decaying. As a result, the number of distilleries decreased; there was no mass drinking among the peasants. The peasantry's attachment to the land and strong community traditions that governed the level of alcohol consumption by the population also influenced the fight against drinking. The fiscal policy of the state has led to negative consequences in the fight against alcoholism. Replacing pubs by taverns, introducing the bottled vodka retail trade and increasing in drinking establishments led to the appearance of street alcohol abuse.

The introduction in 1894 of a state wine monopoly streamlined the production and sale of alcoholic beverages. The government committed restrictions on the sale of vodka and gave rural communities a right to sell alcohol on their territory independently. However, the fiscal interests of the state led to quantitative growth of drinking establishments and their structural change. The Katerynoslav Governorate [Province] was the first among other governorates of the Russian Empire in the consumption of alcohol. By 1913, the general level of alcohol consumption in the state decreased from 14.76 liters to 3.6 liters annually per capita.

In the 1860s and 1880s, the fight against alcoholism among the rural population was provided locally, mainly by priests and rural communities. From the 1890's, there were created the Guardianships of Public Sobriety (the Guardianships), which chief purpose was to distract the people from drunkenness by organizing free time for the population. The rural population in the South of Ukraine was assisted by the county Guardianships. Their primary measures in the fight against alcoholism were the following: conducting folk lectures, talks and readings; opening of tea rooms, canteens and reading libraries; organizing festivities. In the late XIX century, due to the reduction of estimates for the Guardianships, they were unable to finish their work.

Originality. For the first time, the impact of the excise tax system reform and the state wine monopoly on the level of alcoholization of the Southern Ukraine rural population has been determined. Also, the activities of priests and the Guardianships of Public Sobriety in the fight against alcoholism in region's villages have been revealed.

Conclusion. The fight against alcoholism among the rural population in southern regions of Ukraine in the second half of the XIX - the beginning of the $X X$ centuries was carried out within the framework of excise system reforms and the state wine monopoly. The Russian government realized the need to develop a system of measures aimed at preventing the alcoholization of population and, - at the same time, stablishing replenishment of the treasury. However, the above mentioned measures did not produce the expected results, since the problem of alcoholism was not fully understood by the state because of the traditional priority of state interests over public ones.

The rural population of Southern Ukraine was characterized by a strong attachment of peasants to the land and deep community traditions that governed the level of alcohol consumption by the population. The rural population consumed three times less alcohol than the urban one. The regional level of the rural population alcoholization was measured by the number of distilleries, their production and the cast of drinking establishments.

The activities of priests and the Guardianships of Public Sobriety showed good results in cultural, educational and moral-religious work among peasants, distracting them from drinking and providing nonalcoholic leisure. However, the state was not ready to support the local constructive initiatives because of financial interests. Generally, the level of drunkenness among the country's rural population has been reduced.

Keywords: peasantry; alcoholism; excise system; state wine monopoly; clergy; Guardianship of Public Sobriety.

UDC 94 (477) “1928/1933”-058.232.6

DOI: $10.31651 / 2413-8142-2019-22-37-42$

Motuz V.

candidate of Historical Sciences, associate Professor, associate Professor of the Department of Archeology and Auxiliary sciences of history of the Bohdan Khmelnytsky National University of Cherkasy

ORCID: https://orcid.org/0000-0002-9974-7205

\section{THE STRUGGLE AGAINST OPPORTUNISM IN THE GRASSROOTS PARTY-SOVIET INSTITUTIONS OF THE UKRAINIAN COUNTRYSIDE DURING THE SECOND "COMMUNIST ASSAULT" (1928-1933)}

In the context of the issue of internal-party confrontation between the Communists in the late 1920s - early 1930s, regarding the need to change the model of economic development of the Soviet Union, and on the basis of a comprehensive approach in the work, the features of combating the "right tendency" in the local authorities and self-government in the Ukrainian countryside during the first 
five-year plan, as well as the attitude of the Ukrainian peasantry to the subjects of political conflict.

Keywords: totalitarianism, early Stalinism period, opportunism, right-leaning movements in the CPSU (b) and $C P(b) U$, grassroots party-Soviet apparatus, grassroots Soviet institutions in the countryside.

Problem statement. The Communist Party sought to build not only a new "ideal" state, but also a new human who would become a devoted builder of the socialist future and an obedient executor of any plans and ideas of the party leadership. To provide the authorities with reliable support meant to deeply embed the dominant ideology in the public consciousness of the broadest sections of the public. This was quite a difficult task, because in many respects the artificial, sometimes overtly contrived, scholastic system of Soviet worldview values and landmarks was incompatible with the moral and ethical principles familiar to the vast majority of the Ukrainian population, that is, the peasantry. Under these conditions, the Ukrainian peasantry actually became a hostage to the powerful ideological machine of the totalitarian regime of the Soviet-Stalinist model.

The process of establishing the Soviet system in the Ukrainian countryside was largely accompanied by the planting of grassroots, purely administrative authorities, party and Komsomol units, Committees of Poor Peasants and other Soviet institutions, whose task was to establish permanent unwavering control over all aspects of countryside life and peasant sentiments.

During the strengthening of Soviet power and the establishment of the Stalinist dictatorship, the second "communist assault" took place, whose executors were noted for their cruelty to the so-called "anti-Soviet elements in the countryside". Introducing it for the ultimate suppression of peasant resistance to Soviet power through collectivization and dekulakization, J. Stalin and his supporters consolidated their result with mass terror under which millstones the party members from local authorities and self-governing bodies with moderate views on governmental regulation of agrarian industry came.

Therefore, the smallest differences with the official party line, especially in tactical issues, in the then oppressive atmosphere of fighting different "biases", could turn into quite serious consequences for the "internal" opponent.

Research analysis. The corresponding issue has been reflected in a number of research and exploration activities. However, it was covered partially, for example, in the context of the research: the Stalinist dictatorship of the period of the second "communist assault" [8], the struggle against the right opposition in the USSR and directly in the Ukrainian SSR [2], the Ukrainian experience of the rotation of executives in the Soviet totalitarian state in the 1920s - 1930s [4], the social peculiarities of the personnel policy of the Communist Party in Ukraine in the 1920s - early 1930s [12], the Soviet leadership's political course on the peasantry during the "great turnout" [5], typology of behavior of rural activists of the Chernihiv okrug of the Ukrainian SSR in the late 1920 s - the early 1930's [9], the resistance of youth against the policy of ruling regime in the Ukrainian SSR during the establishment of totalitarian system (19281936) [10] and so on. Since the problem of combating the "right tendency" in the grassroots party-Soviet institutions of the Ukrainian countryside during the first five-year plan has not been thoroughly and comprehensively reflected in scientific studies, the need for its further in-depth study remains relevant.

The purpose. To reveal the nuances of the government's struggle with the "right tendency" among staff of the grassroots party-Soviet apparatus and rural activists in the early stages of the early Stalinist period.

The statement of the basic material. The general line of the party-Soviet leadership for solid collectivization was accompanied by an unrealistic for realization plan for agrarian production sector of the first five-year plan, so among the Soviet political elite at various levels there were many people who did not support the intensive development of commodity agricultural production in the Soviet Union, proposed by the Stalin's team in the second half of the 1920s.

The fourth, final stage of the ideological and political struggle between the currents of the Communist Party, one of which included the Stalinist ruling majority and the other a "right opposition" led by M. Bukharin, was marked by a clear reluctance of some officials, especially employees of grassroots party-Soviet institutions in the countryside, to mindlessly abide by the directives of the highest authorities and administrations of the Ukrainian SSR [2, 124].

The result of this internal party confrontation of 1928-1929 was the official accusation of M. Bukharin and his supporters, at the combined April plenum of the Central Committee and the Central Committee of the CPSU (b) (1929) in opportunism, which announced the next personnel purge throughout all vertical of authorities in Soviet republics $[8,127]$.

And despite the fact that the opposition leaders, not being radical opponents of the government, immediately gave up all struggle against it, acknowledging the falsity of their political judgments [2, 124], criticizing their position and directly harassing the supporters of that political line - continued throughout throughout the first five-year plan. For example, in the directive of the Secretary General of the Central Committee of the Communist Party of Ukraine (b), S. Kosior dated October 20, 1931, emphasized the urgent need to identify and decisively suppress the right tendency sentiment in the Communist Party until the immediate removal of "apostates" from its circle [9, 273]. Therefore, during 1929-1931 about 250,000 members were expelled from its ranks, the vast majority of whom were accused of the so-called "right tendency" [4, 451]. However, it should be emphasized that the punishment for the "disobedient" party members until the end of the first five-year plan was the disciplinary withdrawal or expulsion from the Communist Party, which is impossible to say about the following years $[9,274]$.

Mass communication was one of the main tools of the Soviet power's struggle with "right tendency" on the ground. Among the latter, the leading role was played by the print media. For example, on the pages of newspaper "The New Village" in Nizhyn and "The Peasant Truth" in Uman, it is possible to get acquainted with the current situation regarding the "right tendency" in the ranks of the Communist Party on the ground [2, 127].

During the second "communist assault", the Soviet press promoted that topics. By publishing materials on the existence of opportunistic practices in village 
councils and kolkhozes, as well as the ways of cutting it down, the editorial offices of the print media attributed all the shortcomings and mistakes in the policy of the Soviet authorities in the countryside to deceptive rightoppositionists. This was reported in "The Communist" newspaper, for example, in "The Consequences of Peaceful Inclusion" and "The Right-Tendency Practice in the Conduct of Mercenaries". In the first one, the author, on the example of the village council chief-kulak from one of the villages of the Proskuriv okrug, proves the flaw of M. Bukharin's theory of "the inclusion of a wealthy peasant into socialism". The second was devoted to the problem of mercenarism, namely the shortcomings in working with the poor strata of the countryside of Zinovievsk District, in which the opportunists were accused again $[2,128]$.

The main logical explanation for the existence of the "right tendency" in the environment of the Soviet asset of the countryside was the preservation the traditional peasant social landmarks by some parts of it, and hence the latter's unwillingness to participate in the destruction of the way of life of the peasant society of that time. Such "solidarization" with the peasantry arose also as a result of the awareness of some local party-Soviet officials of the increasing of negative sentiment among the peasantry due to the radicalism of political and economic campaigns introduced in the Ukrainian countryside during the "great turnout" years $[9,275]$.

A striking demonstration of the absence of one hundred percent "Komsomol firmness" as a manifestation of political loyalty to the Stalinist totalitarian regime is the reaction to the solid collectivization and dekulakization of representatives of the Komsomol grassroots asset, the vast majority of whom were openly dissatisfied with the grain procurements measures. In particular, the reports of the leading Komsomol authorities indicated "anti-Soviet actions" of LCSYU members in Dnipropetrovsk, Poltava, Kharkiv and other okrugs of the Ukrainian SSR [10, 154].

Examples of passive opposition to Stalin's economic policies in the countryside are the very low statistics of quality in the work of some grassroots party-Soviet leaders. Thus, according to the data for 1929, two incidents took place in the Dzhulinsky district of the Tulchyn okrug: sabotage of grain harvests in Luhove village, with the direct participation of the head of the village council-Komsomol member in it and the refusal of the Komsomol member of Shumylove village to organize a demonstrative act of condemning "bread speculators" $[10,155]$.

Another evidence of non-fulfillment of their direct duties was the "anti-Soviet activity" of members of some grassroots Komsomol units in the Olishiv district of the Chernihiv okrug, who in June 1929, during the grain procurement, not only loyally treated the lack of bread, but also help to peasants who didn't execute a plan to surrender grain, to buy goods to which the latter would be entitled only after the proper fulfillment of their obligations to the state $[9,272]$.

Even further the head of the agricultural artel G. Petrovsky hamlet Lenden of Komariv district of the above-mentioned district Zakhariy Chub went, who at once refused to carry out the dekulakization, openly stating that he "will not rob people". Although mostly activists who did not want to be seen in the infamous grain procurements company left the village under different pretexts $[9,273]$.

The corresponding manifestations of apostasy and disobedience in the ranks of the grassroots Komsomol and economic assets of the countryside, their bold statements about unrealistic for realization plans for total collectivization, as well as their unwillingness to participate in dekulakization, were interpreted by the grassroots Party-Soviet leadership of the Ukrainian SSR as "the right tendency" [1, 198].

So, notwithstanding some differences in the content of the political programs of the Stalinists and Bukharists regarding the transition period, the heads of state institutions in the countryside, who mostly supported the Stalinist course for "solid collectivization" and "dekulakization", without delaying start the active struggle against among representatives of grassroots administrative authorities, party and Komsomol branches, committees of poor peasants and other Soviet institutions [7, 205].

However, there were no real threats to the implementation of the Stalinist political and economic project in the village by the "right tendency", because a well-organized and large-scale intra-party resistance movement on the ground in the Ukrainian SSR did not exist in principle [5].

Taking advantage of the lack of active resistance of the dekulakizated peasants, the Communist-Soviet apparatus focused on its own links, whose employees, without due enthusiasm, and sometimes even irresponsibly, were involved in the implementation of the state agrarian project $[11,134]$.

However, only to the above, the struggle against domestic political opponents in rural areas was not limited. Confirmation of the struggle against "anti-Soviet elements" among the local cadres in the countryside was a joint resolution of the HMRC and the RSFSR RNA of June 28, 1929 "On extending the rights of local councils to facilitate the implementation of national tasks and plans", which was elaborated by the HMRC and the RNC of Ukrainian SSR after the week - at July 3. The contents of this document created a very favorable ground for social tension in the countryside. First of all, the inevitable confrontation at the rural gatherings of representatives of different sections of the peasantry, due to the implementation by the party-Soviet leadership the mandatory planning tasks for the grain procurements $[11,115]$.

Despite the fact that the majority of the village councils were characterized by a rather active participation in total collectivization and dekulakization, for which they were considered to be a reliable support of the Soviet authorities in the countryside, there were also those who, according to the opinion of highest authorities, did not properly belong to fulfillment of their political and economic tasks. For example, the deputy chairman of the ODPU G. Yagoda in one of the reports emphasized the "rocking" that was revealed among certain groups of staff of the Soviet apparatus in the countryside in seven okrugs of Ukraine related to loyalty to kulaks $[11,127]$. In order to remedy this shortcoming and, accordingly, to improve the country-wide indicator of their activity in the future, re-elections to village councils were organized without any delay $[11,134]$.

In spite of the gradual increase in the number of party cells, they were still weak, both numerically and 
morally, during the period, and thus unable to properly influence the positive attitude of the rural population to the Soviet power. Thus, in the party documents at the time it was constantly stated that their influence on the villagers was negligible - the peasants regarded them as "aliens" $[15,101]$. At the beginning of 1928 , there were 37,800 communists in 2,609 rural party cells. Over the next two years, their number has not increased much: rural party cells by $12 \%$, which amounted to 2,910 , and Communists by $6 \%-40,000[3,213-214]$.

Their main task was to promote the idea of collective management and organizational work to involve peasants in kolkhozes. However, some of the rural party members, who sincerely accepted the slogan that the main purpose of the Soviet government was to serve the interests of the working people, did not want to become a blind instrument of a policy of forced collectivization that carried no good to the peasant. In response to such sentiment, in July 1929, the Central Committee of the CPSU (b) launched a broad campaign of checking and purges of rural party cells in Ukraine $[14,1]$.

It should be noted that the peasants showed great interest in the party purges, as indicated by some materials of the official documents of that time: "The meetings dedicated to cleaning are held in the presence of the peasants. Starting at $6 \mathrm{pm}$ until late at night, no one go away... 270,096 people at the 107 districts attended the purges meetings" $[13,119]$. Such a high level of socio-political activity of the rural community was caused, first of all, by problems in the economic sphere. At open-entering meetings, the peasants tried to support those party members who held firm views on resolving acute economic challenges and sought to counteract the most aggressive leaders of anti-peasant ideas.

The purge was tough. In a number of cases, the entire composition of the party cells was completely updated. For example, of the 33 communists tested in the Chervono-Povstansk district of Odessa okrug, 26 were eliminated, ie $79 \%$ of party members. In the Dnepropetrovsk okrug, the control commission of the District Party Committee completely dissolved 10 cells. Regarding the formal reasons for deprivation of the party card, they stated the following: separation from the party (26\% of charges), "alien element" (17\%), drunkenness $(17 \%)$, squandering (13\%), former military service of the White Guards, Hetmanists, participation in "the gang", desertion from the Red Army (10\%), connection with the kulak element (6\%), economic overgrowth (6\%), observance of religious rites $(4 \%)[13,122]$.

Despite several years of struggle against the party opponent in the countryside, this challenge had not been finally resolved by the end of the first five-year plan. For example, in the reporting information of the Chernihiv Regional Committee of the $\mathrm{CP}(\mathrm{b}) \mathrm{U}$, it was pointed out that 255 facts of counteraction of local grain-harvesting personnel (rejection of plans and evasion of work, refusal to hand over grain, "right tendency conversations") were revealed in 27 districts of the region. For such anti-Soviet actions, 16 responsible district workers, 18 authorized persons of district committees of the $\mathrm{CP}(\mathrm{b}) \mathrm{U}, 22$ chairmen and members of village councils, 12 cell secretaries, 34 chairmen and board members of kolkhozes and 27 representatives of a rural asset lost their posts $[9,274$ 275].

Moreover, since 1933, the methods of combating opportunism in the Communist Party were no longer limited to dismissal or expulsion, since the "purge" began to fall within the legal qualification of a criminal offense. Taking the same Chernihiv Oblast as an example, according to the statistics of its oblast party organization, 5 responsible district workers, 7 authorized persons of district committees of the $\mathrm{CP}(\mathrm{b}) \mathrm{U}, 15$ heads and members of village councils, 11 cell secretaries, 31 chairmen and board members of kolkhozes, as well as 17 representatives of rural assets were arrested and sentenced [9, 278].

This "action" was purely terrorist in nature, so it was intended to intimidate the rural party members and leave in the party cells only those who were able to blindly pursue the course of total collectivization of agriculture. The visual demonstration of terror and the continued fear of being repressed shaped the irresponsible executors of the plans to forcefully "force" the peasants into the kolkhozes, to seize food and to passively inactivity during the Holodomor of 1932-1933.

In the same year, in exchange for "purified communists", 15,928 people were sent to rural areas from the industrial regions of Ukraine, who held the lion's share of leading positions in power institutions of the grassroots [6, 191].

However, since November 1933 (the combined plenum of the Central Committee and the Central Committee of the $\mathrm{CP}(\mathrm{b}) \mathrm{U})$, the high party-Soviet leadership has shifted from "right opportunism" to "nationalist tendency" in the ranks of the Communist Party. According to this, a new round of "purges" has started, since, according to the republican state-party leadership, this challenge was "the main danger" for the Communist-Soviet system of state power in Ukraine [8, 130].

The conclusions. Thus, the process of asserting Soviet power in the Ukrainian countrysidee was accompanied not only by the administrative strengthening of the authorities, party cells, and other Soviet structures, which could help to strengthen control over the peasants and daily bring to their minds the postulates of the communist doctrine, but also the open terror - perverted purges in their ranks to ensure the complete subjugation of grassroots executive structures and the smooth execution of any orders from above.

Today, the study of peasant issues, as a whole, and especially its constituents, such as the activities of local government and self-government, is insufficient, and therefore needs further research.

\section{Bibliography:}

1. Васильєв В. Політичне керівництво УРСР і СРСР: динаміка відносин центр-субцентр влади (1917-1938). Київ: Інститут історії України НАН України, 2014. 376 с.

2. Греченко В. Завершення боротьби 3 «правою опозицією» (1930р.). Вісник Харківського національного університету внутрішніх справ. 2006. Вип. 33, С. 124-132. 3. Історія Украӥнської РСР: Украӥнська РСР у період побудови та зміинення соиіалістичного суспільства (19211941: у 8 т. / ред. П. Гудзенко. Київ : Наук. думка, 1977. Т. $6.543 \mathrm{c}$.

4. Дорошко М. Ротація керівних кадрів у радянській тоталітарній державі у 1920-1930-ті роки: український «досвід». Проблеми історії Украӥни: факти, судження, пошуки. 2007. №16(1), 445-455.

5. Житков О. Кіровоградський державний педагогічний університет ім. В. Винниченка, кафедра історії України Політика ВКП(б)-КП(б)У щодо селянства (I928-I929 рр.). [Електронний ресурс]. - Режим доступу: http:// ena.lp.edu.ua/bitstream/ 
6. Єфіменко Г. Національні аспекти у формуванні компартійно-радянського апарату в УРСР (1932-1938). Украӥнський історичний журнал. 2000. №6. С. 184-200.

7. Капустян Г. Комітети незаможних селян у системі радянсько-більшовицької політики, Український селянин. 2005. Вип. 9. С. 203-207.

8. Кульчицький С. Сталінська диктатура в період другого комуністичного штурму (1929-1938рр.). Проблеми історіі Украӥни: факти, судження, пошуки. 2012. Вип. 21, С. 118 134.

9. Лисенко О. Сільські активісти Чернігівщини (кінець 1920-1930-ті рр.): типологія поведінки. 3 архівів ВУЧК ГПУ, НКВД, КГБ. 2013. № 1-2. С. 255-284.

10. Прилуцький В. Опір молоді політиці правлячого режиму в УСРР в період утвердження тоталітарного ладу (1928-1936 рр.). Проблеми історії Украӥни: факти, судження, пошуки. 2000. Вип. 5. С. 152-184.

11. Історія украӥнського селянства: у 2 т. / ред. В. Смолій. Київ : Наук. думка, 2006. Т. 2. 653 с.

12. Степанчук Ю. Соціальні особливості кадрової політики КП(б)У (20-ті - початок 1930-х рр. ХХ ст.). Наукові записки Віннииького державного педагогічного університету імені Михайла Коиюбинського. 2004. Вип. 7. С. 45-49.

13. ЦДАВОУ, Ф. 1, Оп. 4, Спр. 9. Протоколи й стенограми засідань бюро комуністичної фракції IV сесії ВУЦВК X скликання. Протокол і стенограма засідань голів окрвиконкомів про політичний стан на селі, проведення шляхового будівництва і хлібозаготівельної кампанії на Україні. - 25.11.1928. - 25.01.1929, 200 арк.

14. ЦДАГОУ, Ф. 1, Оп. 7, Спр. 467. Матеріали до протоколів № 101-102 засідань Оргбюро та Секретаріату ЦК КП(б)У. - 19.04. - 21.04.1937, 203 л.

ЦДАГОУ, Ф. 1, Оп, 20. Спр. 2824. Огляди № 9, 16, 17, 20 23, 27, 28 інфрмаційного відділу ЦК КП(б)У про політичні настрої робітників, селян і червоноармійців. - 23.02. $25.10 .1928,104$ л.

\section{References:}

1. Vasiliev, V. (2014). Political Leadership of the Ukrainian SSR and the USSR: Dynamics of Center-Subcenter Relations (1917-1938). Kyiv: Institute of History of Ukraine, National Academy of Sciences of Ukraine, 376 p. [in Ukr.]

2. Grechenko, V. A. (2006). Completion of the Struggle Against the "Right Opposition" (1930). Bulletin of the Kharkiv National University of Internal Affairs, 33, pp. 124-132. [in Ukr.]

3. Gudzenko, P. (Ed.). (1977). History of the Ukrainian SSR: The Ukrainian SSR in the Period of Building and Strengthening the Socialist Society (1921-1941) (in 8 volumes, Vol. 6). Kyiv: Naukova Dumka, 543 p. [in Ukr.]

4. Doroshko, M. (2007). Leadership Rotation in the Soviet Totalitarian State in the 1920s and 1930s: the Ukrainian "Experience". Issues of the History of Ukraine: Facts, Judgments, Searches. 16 (1), pp. 445-455. [in Ukr.]

5. Zhytkov, O. V. Vynnychenko State Pedagogical University of Kirovohrad, Department of History of Ukraine. The Politics of the CPSU(b) - CP(b)U Concerning the Peasantry (I9281929). Access mode: http://ena.lp.edu.ua/bitstream/ [in Ukr.] 6. Efimenko, G. (2000). National Aspects in the Formation of the Communist Party Apparatus in the Ukrainian SSR (1932-1938). Ukrainian Historical Journal, 6, pp. 184-200. [in Ukr.]

7. Kapustyan, G. (2005). Committees of Poor Peasants in the System of Soviet-Bolshevik Politics, 9, pp. 203-207. [in Ukr.]

8. Kulchytsky, S. (2012). Stalin's Dictatorship During the Second Communist Assault (1929-1938). Issues of the History of Ukraine: Facts, Judgments, Searches, (21), pp. 118-134. [in Ukr.]

9. Lysenko, O. (2013). Rural Activists of Chernihiv Region (Late 1920s-1930s): Typology of Behavior. From the Archives of VUCHK, GPU, NKVD, KGB, (1-2), pp. 255-284. [in Ukr.]
10. Prylutsky, V. (2000). Youth Resistance to the Policies of the Ruling Regime in the Ukrainian SSR During the Period of the Establishment of the Totalitarian System (1928-1936). Issues of the History of Ukraine: Facts, Judgments, Searches, (5). pp. 152-184. [in Ukr.]

11. Smoliy, V. A. (Ed.). (2006). History of the Ukrainian Peasantry. (in 2 vols., vol. 2). Kyiv: Naukova Dumka, 653 p. [in Ukr.]

12. Stepanchuk, Y. S. (2004). Social Peculiarities of the Personnel Policy of CP(b)U (20's - beginning of 1930s). [in Ukr.]

13. TsDAVO of Ukraine. F. 1. Op. 4. Spr. 9. Minutes and Transcripts of the Meetings of the Communist Fraction Bureau of the IV Session of the All-Ukrainian Executive Committee of the Xth Convocation. Minutes and Transcript of the Meetings of the Heads of Executive Committees on the Political Situation in the Countryside, Conducting Road Construction and Grain Procurement Campaign in Ukraine. - 25.11.1928. - 25.01.1929, 200 ark. [in Ukr.]

14. TsDAVO of Ukraine. F. 1. Op. 7. Spr. 467. Materials for Minutes No. 101-102 of the Meetings of the Organizing Bureau and the Secretariat of the Central Committee of the CP(b)U. 19.04. - 21.04.1937, 203 ark. [in Ukr.]

15. TsDAVO of Ukraine. F. 1. Op. 20. Spr. 2824. Surveys No. 9, 16, 17, 20, 23, 27, 28 of the Information Department of the Central Committee of the Communist Party (b) of Ukraine on the Political Attitudes of Workers, Peasants and Red Army Servicemen. - 23.02. - 25.10.1928, 104 ark. [in Ukr.]

\section{В. Мотуз}

\section{БОРОТЬБА 3 ОПОРТУНІЗМОМ У НИЗОВИХ ПАРТІЙНО-РАДЯНСЬКИХ ІНСТИТУЦІЯХ УКРАЇНСЬКОГО СЕЛА ПІД ЧАС ДРУГОГО «КОМУНІСТИЧНОГО ШТУРМУ» (1928-1933)}

Постановка проблеми. Комуністична партія прагнула будувати не тільки нову «ідеальну» державу, але й формувала нову людину, яка б стала відданим будівником соиіалістичного майбутнього та слухняним виконавием будь-яких планів $і$ задумів партійної верхівки. Забезпечити владі надійну підтримку означало глибоко вкоренити в суспільну свідомість найшириих верств громадян панівну ідеологію. Це було доволі складним завданням, оскільки багато в чому штучна, інколи відверто надумана схоластична система радянських світоглядних иінностей та орієнтирів, була несумісною зі звичними для більшості українського населення, тобто селян, морально-етичними принципами. За ичих умов українське селянство фактично стало заручником потужної ідеологічної машини тоталітарного режиму радянськосталінського зразка.

Утвердження радянського ладу в українському селі супроводжувалося значною мірою насадженням низових, суто адміністративних органів влади, партійних і комсомольських осередків, комітетів незаможних селян та інших радянських інституцій, завданням яких було встановлення постіиного неослабного контролю над усіма сторонами життя села та настроями селянства.

Під час зміцнення радянськоӥ влади та встановлення сталінської диктатури відбувався другій «комуністичний штурм», виконавциі якого відзначилися своєю жорстокістю до так званих "антирадянських елементів на селі». Його проведення супроводжувалось масовим терором, під жорнова якого потрапили представники низового партійно-радянського апарату та 
громадського активу села, які мали помірковані погляди на державне регулювання відносин у сфері аграрного виробничтва.

Тож, найменші розходження з офіиійною партійною лінією насамперед в тактичних питаннях у тодішній гнітючій атмосфері боротьби 3 «правим ухилом», могли обернутись для «внутрішнього» опонента досить серйозними наслідками.

Автор статті ставить за мету розкрити нюанси боротьби радянської влади з «правим ухилом» серед прачівників низових ланок партійнодержавного апарату та представників громадського активу села в Украӥні у роки першоі n'ятирічки.

Основні результати дослідження. Для закріплення перемоги у внутрішньопартійному протистоянні 1928-1929 рр. над правою опозицією, очолюваною М. Бухаріним, Й. Сталін та його оточення, звинувативши своїх опонентів в опортунізмі, анонсували кадрову чистку по всій вертикалі влади в усіх радянських республіках.

С підстави говорити про те, шо

- на початковому етапі радянськоі модернізачії серед працівників низових ланок партійно-державного апарату та представників громадського активу села було чимало тих, хто відмовлявся «беззаперечно додержуватись генеральної лінії вищого партійно-державного керівниитва Радянського Союзу» щзодо необхідності, темпів та методів запровадження суиільної колективізації в Україні;

прояви опортуністської поведінки в партійно-радянському середовищі на селі не набули великих масштабів. Однак ії наявність протягом всієї першої п'ятирічки по всій території України дала підстави вищому партіино-державному керівниитву Радянського Союзу та відповідно УСРР змінити в 1933 р. практику заходів боротьби з нею: відмовитися від просто усунення із займаних посад інакодумиів та безпосередньо перейти до їх арештів й тюремного ув'язнення;

проблема боротьби проти правоухильників перебувала в центрі уваги сільського населення Украйни. Селянство проявило високий ступінь лояльності до них. Таке виявлення політичної активності сільського загалу було викликано насамперед негараздами в економічній сфері, тому співчуваючи селяни намагались всіляко підтримати тих партійців, які дотримувались тверезих поглядів на шляхи вирішення гострих економічних проблем $i$ прагнули протидіяти найбільш агресивним провідникам антиселянських ідей.

Висновки. Таким чином, початковий етап періоду раннього сталінізму в українському селі відзначився не лише адміністративним зміцненням органів влади, партійних осередків та інших радянських структур, які могли сприяти посиленню контролю над селянством і повсякденно привносити в їх свідомість постулати комуністичної доктрини, але й відвертим терором - черговою кадровою чисткою у своїх лавах задля забезпечення иілковитого підкорення низових виконавчих структур $i$ громадського активу села та безвідмовного виконання ними будь-яких наказів зверху.

Ключові слова: тоталітаризм, радянський тоталітаризм в Украӥні, початковий етап періоду раннього сталінізму в Україні, опортунізм, правоухильницька течія у КП(б)У.
УДК 94(470+571)"19/20"

DOI: $10.31651 / 2413-8142-2019-22-42-46$

3. В. Священко

доктор історичних наук, професор кафедри всесвітньої історії та методик навчання Уманського державного педагогічного університету імені Павла Тичини

ORCID: http://orcid.org/0000-0001-5845-3115

\section{СЕЛЯНСЬКАГОМАДАВУРЯДОВИХПРОЕКТАХ РОСІЙСЬКОЇ ІМПЕРІЇПОЧАТКУХХСТ.}

У статті проаналізовано проекти представників урядових кіл шодо ролі та значення селянської громади в Російській імперї початку ХХ ст. Доведено, шчо потреба в реорганізачії аграрнӧ̈ політики по-своєму, але усвідомлювалася урядовими колами Російської імперії.

Ключові слова: селянство, аграрне питання, Російська імперія, Особлива нарада, Редакиійна комісія, селянська громада.

Постановка проблеми. Селянська громада, яка охоплювала більшість як селянських господарств, так і селянської землі мала великий вплив на розвиток сільського господарства Російської імперії в пореформений період. Наприкінці XIX - на початку $\mathrm{XX}$ ст. громада чинила певний негативний вплив на розвиток селянського господарства, але ці вади урівноважувалися великою кількістю того корисного, що робила громада для селян. Тому в російському суспільстві були послідовні прихильники поземельної селянської громада. Вони перебували під впливом тих сил, які індивідуалістському Заходові прагнули протиставити громадівську Русь, розглядаючи громаду як головну умову збереження старих порядків. Разом із тим були й ті, хто доводив переваги приватновласницького землеволодіння перед громадівським. Питання ролі громади дедалі більше цікавило представників російської громадськості, перебувало в центрі багатьох дискусій.

Саме початок XX ст. в історії Російської імперії позначений актуалізацією аграрного питання, яке перебувало у фокусі постійної уваги урядовців. Неодноразово власті ініціювали створення різноманітних комісій, які б вивчили стан справ на селі та розробили пропозиції щодо його удосконалення. Вважаємо за потрібне зупинитись на діяльності декількох із них, напрацювання яких стосувалося останніх досліджень долі селянської громади.

Аналіз досліджень. Історія селянської громади в Російській імперії розглядалася в працях П. Зирянова [1], який вперше в історіографії акцентував увагу не на проблемах реформування аграрних відносин, а на процесах в сільській громаді; також у дослідженнях П. Кабитова [2], Л. Кучумової [3], Ю. Лебедєва [4] та ін. Проблема, що досліджується, певним чином розглядалася у працях В. Леонтовича [5], С. Сидельникова [6], М. Симонової [7], І. Щербакової [8] та інших авторів. Однак їх праці більшою мірою стосуються загальної характеристики аграрної політики російського царату. Питання селянського самоврядування у пореформений період $\epsilon$ предметом дослідження I. Верховцевої [9], I. Касяна [10] та інших істориків. 